\title{
Histo-cytological study of the graft union of the Chestnut (Castanea sativa Mill)/Oak (Quercus vulcanica Boiss)
}

\author{
Selime ADA*, Engin ERTAN \\ Adnan Menderes University, Faculty of Agriculture, Department of Horticulture, 09100 Aydın, Turkey
}

Email address:

eertan@adu.edu.tr(Engin ERTAN)

\section{To cite this article:}

Selime ADA, Engin ERTAN. Histo-Cytological Study of the Graft union of the Chestnut (Castanea Sativa Mill)/Oak (Quercus Vulcanica Boiss) . Agriculture, Forestry and Fisheries. Vol. 2, No. 2, pp. 110-115. doi: 10.11648/j.aff.20130202.18

\begin{abstract}
Graft compatibility is a complex mechanism with a wide range of different physiological, biochemical, and anatomical interactions. In the present paper, features of the graft union on the combination of the European chestnut (Castanea sativa Mill.) on an oak (Quercus vulcanica Boiss.) rootstock based on whip grafting was investigated. The trial was conducted in the greenhouse at the Faculty of Agriculture, Adnan Menderes University, in western Turkey during 2006-7. The grafts were made with scion from chestnut genotype N-3-4 on an oak rootstock. Cross and longitudinal sections of the graft union for examination were taken 30, 60, 90, 120, 150 and 210 days after grafting, and fixed in $70 \%$ ethanol. Microscopic observation of the anatomical and histo-cytological structure of the graft union area revealed that new cambium, xylem, and phloem tissues were formed in the samples 120 days after grafting. The results showed that, graft compatibility exists between chestnut and oaks. Callus formation and differentiation of vascular tissues started 150 days after grafting.
\end{abstract}

Additional index words: Chestnut, Oak, Anatomy, Histology, Graft Union

\section{Introduction}

Plant grafting is widely used as means of plant propagation and for growth control is of considerable importance in adaptation tests for potential new cultivars. Fruit trees are usually formed by a combination of scion and rootstock. For that combination to be successful, a good union between a scion and rootstock is necessary (Feucht, 1988; Errea et al., 2001). The grafted partners can belong to the same species or genus, but components that are more genetically divergent could also be used. In the latter case, the stock and the scion may not produce a successful graft and show their incompatibility in the form of a failed graft (Pina and Errea, 2005).

Different factors such as inherent system of cellular incompatibility, formation of plasmodesmata, vascular tissue connections and the presence of growth regulators and peroxidases may have an influence on graft success. Macromolecules (phloem proteins, RNA, hormones) that are present in the sap phloem might be also important during vascular differentiation in compatibility process (Pina and Errea, 2005)

Grafting has proven to be more successful and feasible method of asexually propagating chestnuts than any other technique in the chestnut industry (Oraquzie et al., 1998). Grafting within the species, particularly within cultivated populations in chestnuts is sufficiently successful to be used commercially for some cultivars (Rutter et al,. 1990).

Huang et al. (1994) reported that an unusual anatomical structure of the chestnut stem had a significant effect on graft success in graft compatibility studies conducted with 15 Chinese chestnut cultivars, nine American chestnut selections, six Japanese chestnut cultivars and two putative Japanese hybrids on two known rootstocks of Chinese chestnut. Seferoglu and Ertan (2003) stated that callus tissue triggered the cambial differentiation and the first new vascular components began to emerge in cross-section samples one month after budding in Turkish chestnut selections.

In the grafting between different cultivars of the same species generally a well-developed graft union is obtained and normal plants grow (Özçağıran et al., 1974). This situation also applies to chestnuts when their own seedling rootstocks are used for grafting. However, in the literature there is not enough information about a successful graft union between an alternative rootstock and scion cultivar in chestnut grafting. 
While graft union success is limited in grafting between different genera of the same family, some examples of success exist in practice (Özçağıran et al., 1974). Grafting Citrus species onto trifoliate orange (Poncirus trifoliata Raf.), which is resistant to cold weather conditions and a deciduous plant of the Rutaceae family, is a good example for this situation. Oak (Quercus sp.) and beech (Fagus sp.) of the Fagaceae family can be used as alternative species for chestnut grafting apart from chestnut seedlings.

Many studies have been conducted on anatomical and histological structures in graft unions of chestnuts using budding/grafting methods (Ufuk and Soylu, 1999; Seferoğlu and Ertan, 2003; Serdar and Soylu, 2004; Serdar et al., 2005). However, there have been no attempts to investigate the anatomical structure in graft unions using different rootstocks for grafting European chestnuts. Therefore, this study aims to investigate graft union characteristics between chestnut scions and oak rootstocks which naturally grow in the flora of chestnut growing regions. The main objective of this study is to examine the histological structure of whip grafting on chestnut for which oak was used as a rootstock.

\section{Material and Methods}

This study was carried out in the greenhouse of Faculty of Agriculture in Adnan Menderes University in Aydin (Turkey) between the years 2006-2007. Oak trees (Quercus vulcanica Boiss.) were used as rootstocks in this study. Whip grafts were made on 23 March 2006. After grafting, the graft union was tied with parafilm. Dormant buds of the chestnut genotype N-3-4 were used as scion material, which were selected among 80 accessions from natural populations in Nazilli district (Ertan, 2007) at the end of a selection study for higher nut quality and higher yield. One-year-old chestnut scion woods were whip grafted onto two-year-old oak seedlings (Quercus vulcanica Boiss.) in the dormant seasons.

Samples were collected 30,60, 90, 120, 150 and 210 days after grafting to examine the anatomical structure of the graft unions. In each period ten samples selected randomly were taken from each graft combination. The samples were kept in $70 \%$ ethanol. For each sample cross and longitudinal sections of 10 to $50 \mu \mathrm{m}$ thickness representing different parts of the grafting point were taken with a sliding microtome. Cross and longitudinal sections of the samples in ethanol were stained with methylene blue so that the sections are easily recognizable under microscope.

The usual sequence of events in the healing of a graft union has the following steps were examined (Mc Cully, 1983; Hartman et al., 1990).

(a) Establishment of an intimate contact between the cambial regions of stock and scion and production of callus tissue (parenchymatic cells) by both components of the graft in the cambial region. (b) Differentiation of certain parenchymatic cells of the callus into new cambial cells connected the original cambium both in the stock and in the scion.

(c) Production of new vascular tissues (xylem and phloem) by the new cambium, forming the vascular connections necessary for a successful graft union.

\section{Results and Discussion}

\subsection{Comparisons of anatomic structure of oak (Quercus vulcanica Boiss.) and European chestnut (Castanea sativa Mill.)}

Xylem tissue, trache, tracheid and xylem core rays were observed in one-year-old shoots containing a large radiating core during an examination on cross and longitudinal sections taken from oak stem segments. The cells of the xylem core rays were clearly detected. The bark tissue consists of a cork tissue in the outer layer and a large cortex tissue extending to the phloem. In the cortex tissue, a sclerenchymatic ring existed as double-layered sclerenchyma cells. Non-mature sclerenchyma rings stand in the cortex tissue as a whole. The sclerenchyma ring which has not completed its development and is close to the phloem shows a partial situation (Figure 1).

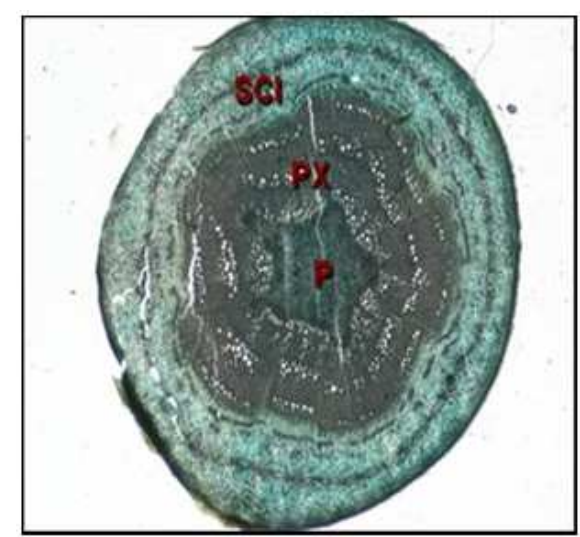

Figure1. View of tissues in cross sections of the oak stem (10x2, methylene blue); Scl-Sclerenchyma, P-Pith, X-Xylem

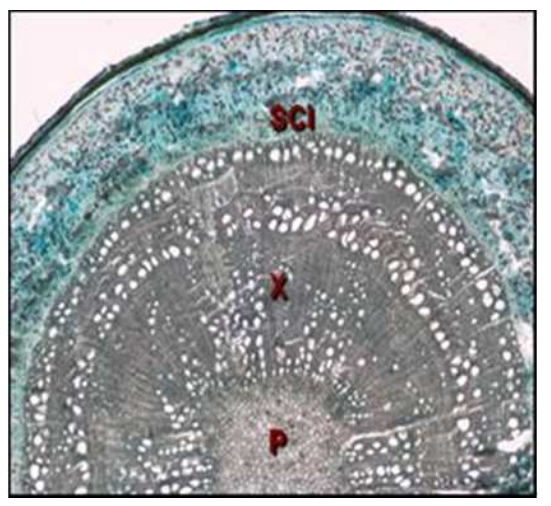

Figure 2. View of tissues in cross sections of the chestnut stem (10x4, methylene blue); Scl-Sclerenchyma, P-Pith, X-Xylem 
In the examination of cross and longitudinal sections taken from one-year-old shoots of chestnuts, a large core space was observed. A large xylem tissue contained a radiating xylem core and parenchyma, trache and tracheids were determined in cross and longitudinal section samples. A double-layered sclerenchymatic ring existed in the cortex tissue where the sclerenchimatic cells scattered. The sclerenchymatic rings of cortex in chestnuts were more disperse than that of in oaks (Figure 2).

The most prominent difference found in the examination of cross and longitudinal section samples of oaks and chestnuts was that the sclerenchymatic ring in the cortex tissue in oaks was integral (surrounded all around). And the sclerenchymatic ring in the cortex in chestnuts was more dispersed and fragile in shape (Figure 1 and 2).

\subsection{Callus and graft union formation in chestnut/oak combinations}

Development of the anatomical and histological structure in this trial in chestnut/oak combinations was investigated on the cross and longitudinally sections, taken from the samples to be grafted with whip grafting techniques, belonging to $30,60,90,120,150$ and 210 days subsequent to grafting.

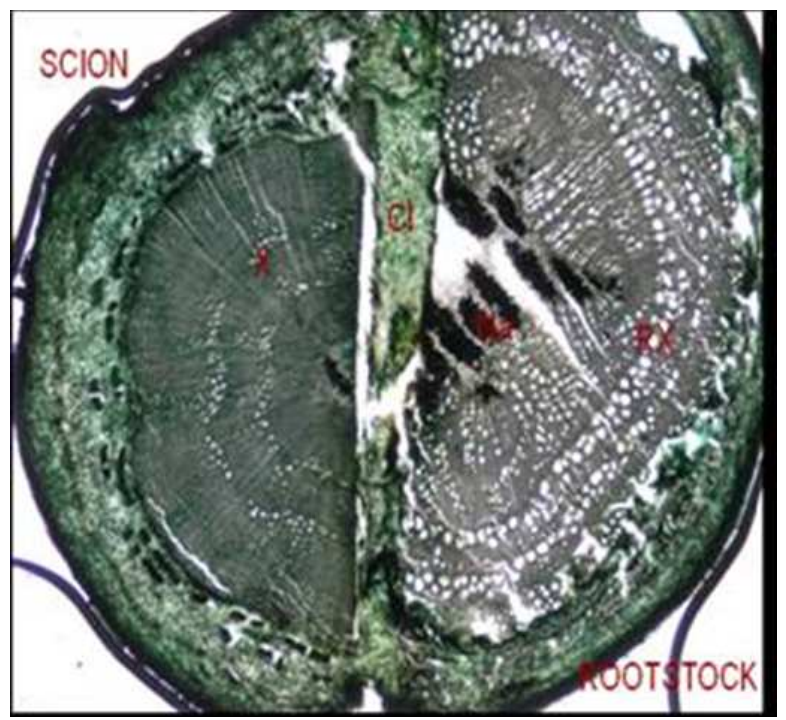

Figure 3. Views of the tissues at the graft union in cross section samples, 60 days after grafting (10x2, methylene blue); X-Xylem, Cl-Callus, $\mathrm{Na}$ Necrotic areas, $R X$-Rootstock xylem

The sections taken after 30 days of grafting showed that the graft union was enabled by callus tissues of rootstock and scion. Some necrotic areas were observed between rootstock and scion. The callus tissue was completely filled the interface between the grafting parts in all samples 60 days after grafting (Figure 3). On the graft interfaces, the formation of thick necrotic areas were observed. On the scion side, a weaker callus tissue develops and the necrotic areas are denser. Some researchers reported that dense necrotic layers acting as a barrier between the stock and scion tissues (Huang et al., 1994; Santamour, 1988;
Craddock and Bassi, 1999). In present study, no excessive dense necrotic layers were observed between the stock and and scion tissues.

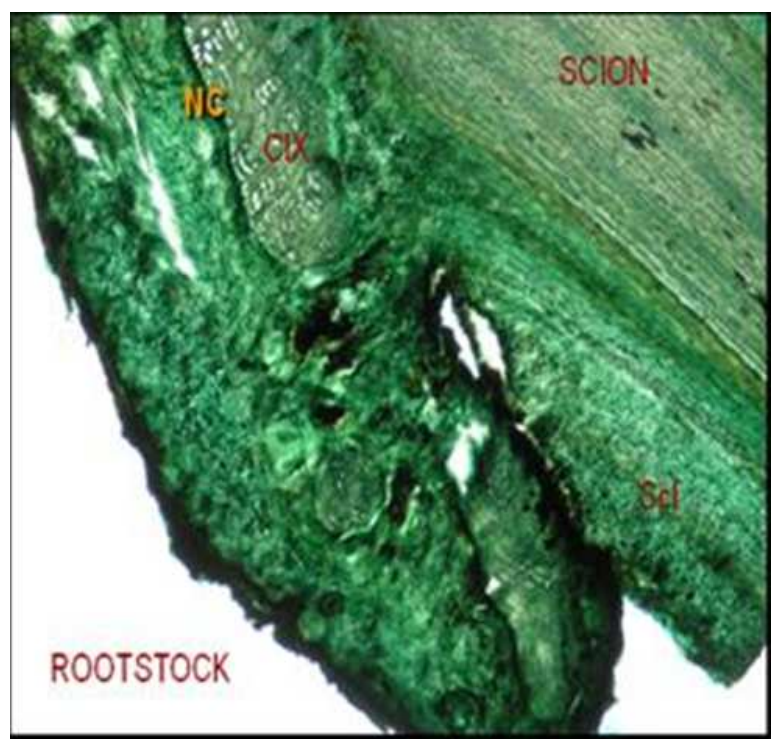

Figure 4. Views of the tissues at the graft union in longitudinal section samples, 90 days after grafting (10x2, methylene blue); NC-New Cambium, ClX-Callus xylem, Scl-Sclerenchyma

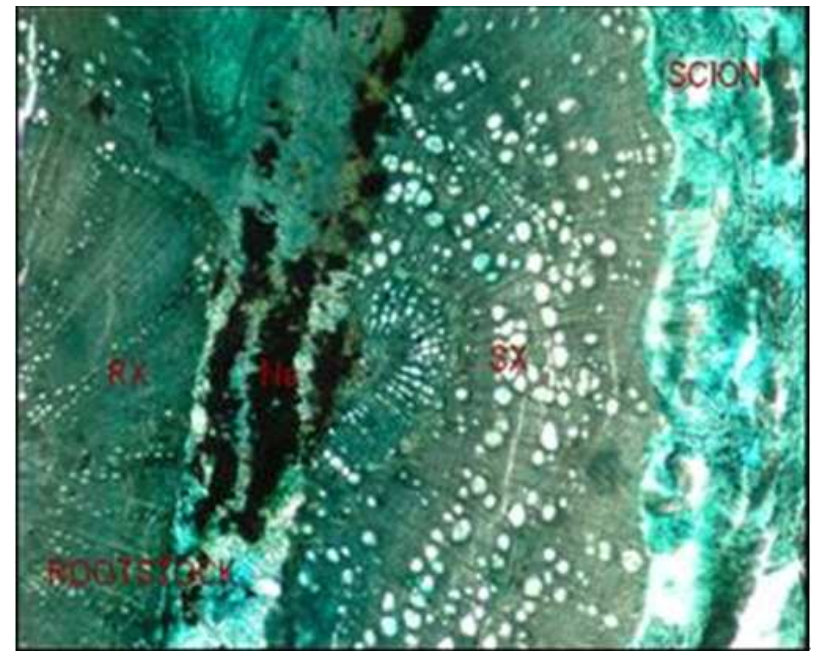

Figure 5. Views of the tissues at the graft union in cross section samples, 120 days after grafting (10x4, methylene blue); $R X$-Rootstock xylem, $\mathrm{Na}$ Necrotic areas, $S X$-Scion xylem

The formation of callus tissue at the graft interface is the first response to grafting (Moore and Walker, 1981). Once the callus has formed, the events that follow this initial formation, when the callus cells first touch, seem to be essential for the critical event deciding the development of future vascular connections (Pina and Errea, 2005). The formation of callus tissue imply some of these compounds in the mechanism of adhesion of the graft partners. Wartlike projections on the cell wall surface have been reported in callus cells at the graft union (Jefree and Yeoman, 1983; Barnett and Weatherhead, 1988). 


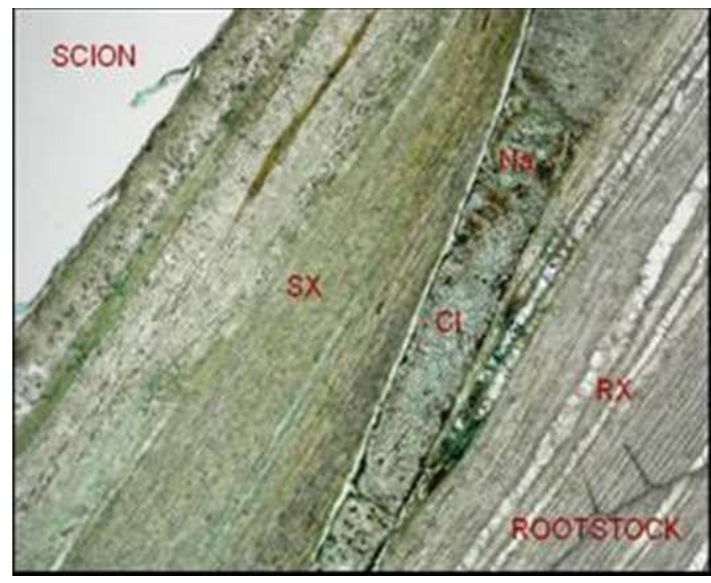

Figure 6. Views of the tissues at the graft union in longitudinal section samples, 150 days after grafting (10x4, methylene blue); SX-Scion xylem, $\mathrm{Na}$-Necrotic areas, Cl-Callus, $\mathrm{RX}$-Rootstock xylem

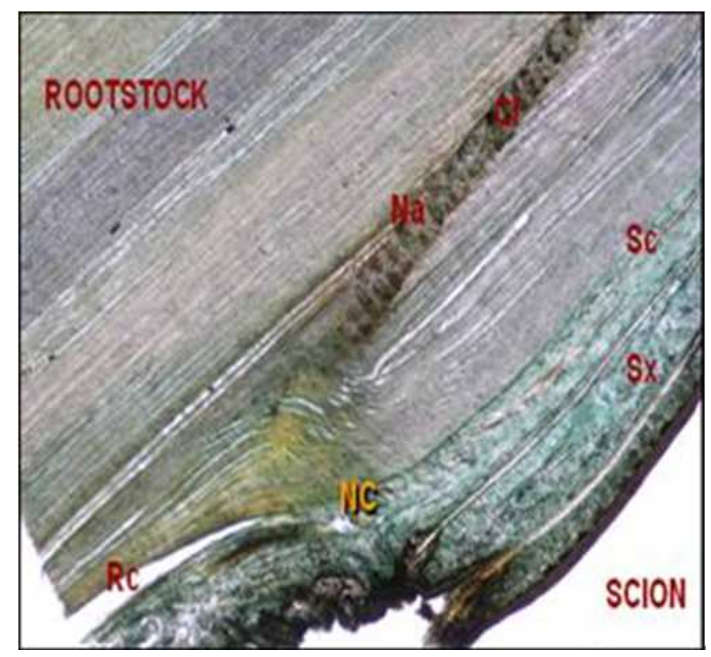

Figure 7. The situation of vascular connection at the graft union in longitudinal section samples, 150 days after grafting (10x2, methylene blue); Cl-Callus, Na-Necrotic areas, SC-Scion cambium, SX-Scion xylem, NC-New Cambium, RC-Rootstosk cambium

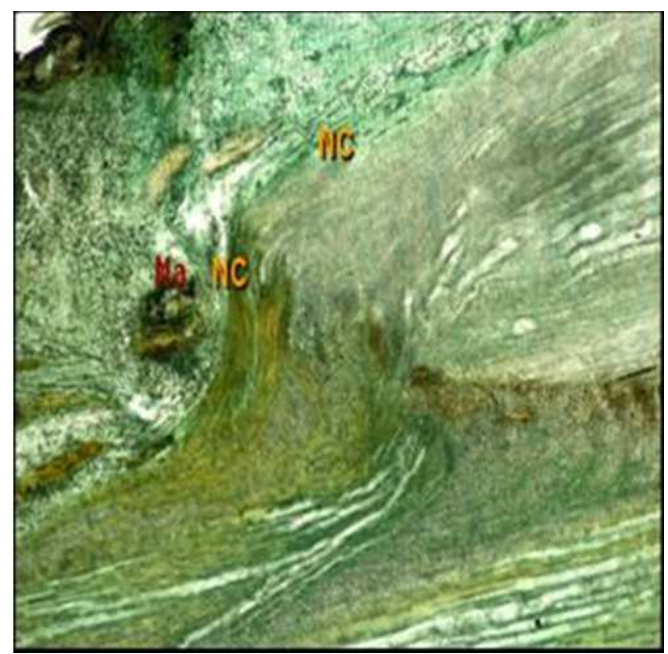

Figure 8. Views of the tissues at the graft union in longitudinal section samples, 150 days after grafting (10x4, methylene blue); Na-Necrotic areas, $\mathrm{NC}$-New Cambium

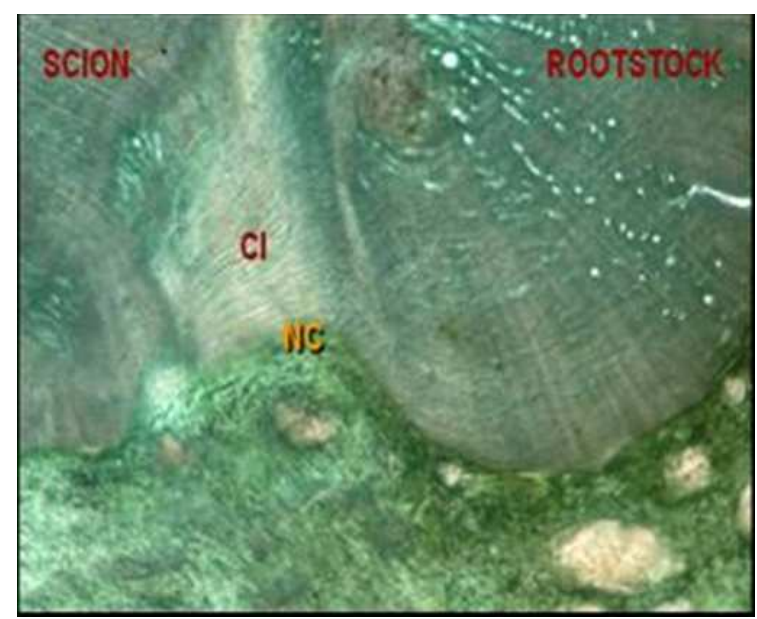

Figure 9. The situation of vascular connection at the graft union in cross section samples, 210 days after grafting (10x4, methylene blue); Cl-Callus, NC-New Cambium

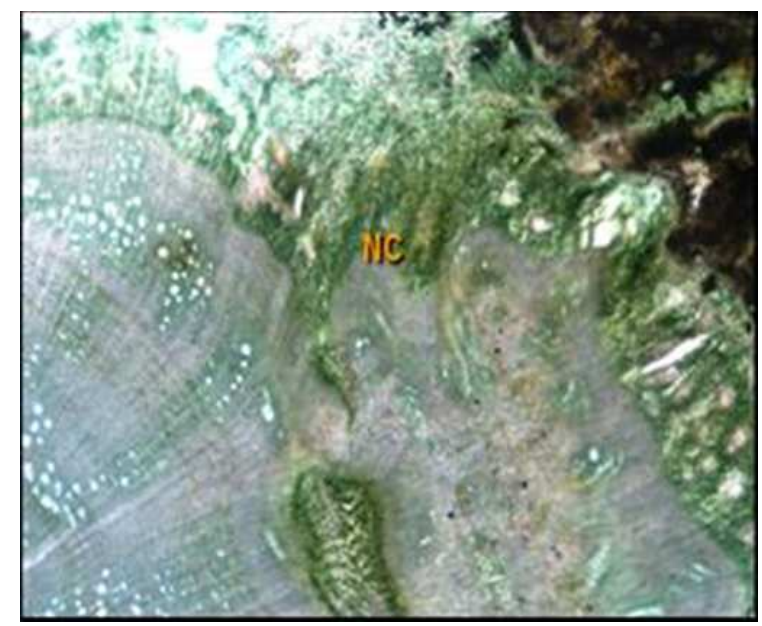

Figure 10. Views of the tissues at the graft union in cross section samples, 210 days after grafting (10x4, methylene blue); NC-New Cambium

In addition, on the cross and longitudinally sections belonging to 90 and 120 days, it is appeared the necrotic areas occurred as a result of oxidation of the phenolic matters during grafting are highly destroyed into small pieces by callus cells. In these periods, the fact that the cambial differention was initiated within the callus tissue, and the first new vascular components began to form in samples is noticed. But in none of the graft samples, the cambial continuity are not established in line of callus bridge yet. 90 days after grafting, cambial tissue at the graft union was differentiated from the callus tissue. New cambium and vascular tissues were formed at the graft union (Figure 4 and 5). Despite the fact that the callus formation occurs as a wound reaction and it is found in compatible and incompatible grafts, the content and nature of the cells involved in the first step of graft formation can play an important role in triggering the responses that lead to the formation of a strong and successful union (Pina and Errea, 2005).

In the last step of graft formation, the formation of vascular connections is considered for most authors the 
basic requirements for a successful graft (Moore, 1984., Wang and Kollmann, 1996). The fact that the new vascular connections could not be not well differentiated or weakly established has been postulated as the main reason for incompatibility in woody plants (Mosse, 1962; Errea et al., $1994 \mathrm{a}, \mathrm{b})$. In the present study, the vascular connection was established successfully between rootstock and scion 150 days after grafting. A few necrotic areas were observed at the graft union, but cambial connection was observed in all longitudinal sections (Figure 6, 7 and 8).

In cross sections made 210 days after grafting, perfect cambial connection were established (Figure 9 and 10). Some researchers have emphasized that cambial connections formed within 45 to $60 \mathrm{~d}$ (Seferoğlu and Ertan, 2003) and, 12 months after grafting (Ufuk and Soylu, 1999; Serdar and Soylu, 2004) in chestnuts. It is possible that this variation may arise from the use of different stock-scion combinations and environmental factors

On the graft success of chestnut scions on to oak rootstocks. Park (1968) reported that $47-55 \%$ viability ratio was reached between Castanea and Quercus genera during experiments with the seed-grafting method in chestnut, ginkgo, and oak species. Heitz and Jacquiot (1972) used the chestnut scions on the oak rootstocks. The anatomical structure of the wood tissues was described around the graft union. The successful cambial development was reported. The grafted trees survived from 1893 until 1946.

The results from this study showed that, graft compatibility exists between chestnut/oak combinations and callus formation and differentiation of vascular tissues was exactly established 150 days following grafting. Such findings confirm existence of graft union between chestnut and oak in the nursery.

The success of grafting depends primarily on the identification of stress and pathogen-resistant rootstocks, and on the compatibility of the graft union in terms of fast formation of the vascular connections between the rootstock and the scion and fast renewal of root and canopy growth (Cohen et al., 2007).

Early graft failure and delayed failure have been recognized in chestnuts (Goldsbrough, 1990; Rutter et al., 1990). The early failures occurred in the first two years, which late failures resulting in scion death at 5-7 years. For this reason, although a vascular connection was established between the chestnut scion and the oak rootstock, the field performance and development of these plants need to be screened in the future for especially delayed incompatibility.

\section{Acknowledgements}

This research was supported by The Commission of Scientific Research Project of Adnan Menderes University. The authors would like to thank The Commission of Scientific Research Project of Adnan Menderes University, for its meritorious support.

\section{References}

[1] Barnett, J. R. and I. Weatherhead, 1988. Graft formation in Sitka spruce: a scanning electron microscopy study. Annals of Botany. 61, 581-587.

[2] Cohen, R., Burger, Y., Koern, A., Edelstein, M., 2007. Introducing grafted cucurbitsto modern agriculture; The Israeli experience. Plant Disease. 91, 916-923.

[3] Craddock, J. H. and G. Bassi, 1999. Effect of clonally propagated interspecific hybrid chestnut rootstock on shortterm graft compatibility with four cultivars of Italian "Marrone". Acta Horticulturae (ISHS), 494: 451-458.

[4] Errea, P., A. Felipe and M. Herrero, 1994b. Graft establishment between compatible and incompatible Prunus spp. Journal of Expermantal Bottany. 45, 393-401.

[5] Errea, P., D. Treutter and W. Feucht, 1994a. Characterization of flavanol-type polyphenols in apricot cultivar and rootstock. Advences in Horticulturel Science. 3, 165-169.

[6] Errea, P., L. Garay and J. A. Marin, 2001. Early detection of graft incompatibility in apricot (Prunus armeniaca) using in vitro techniques. Physiol. Plant. 112, 135-141.

[7] Ertan, E., G. Seferoğlu, G. G. Dalkılıç, F. E. Tekintaş, S. Seferoğlu, F. Babaeren, M. Önal and Z. Dalkılıç, "Selection of Chestnuts (Castanea sativa Mill.) Grown in Nazilli District, Turkey", Turkish Journal of Agriculture and Forestry, 31 (2), 115-123 (2007).

[8] Feutch, W., 1988. Graft incompatibility of tree crops: An overview of the present scientific status. Acta Horticulturae 227: $33-41$

[9] Goldsbrough, G., 1990. A beginner's guide to chestnut growing. Hilton press, Auckland, New Zealand, 40pp.

[10] Hartmann, H. T., D. E. Kester and F. T. Davies, 1990. Plant Propagation. Principles and Practices, 5th edn. Prentice-Hall, $647 \mathrm{pp}$.

[11] Heitz, R. and C. Jacquiot, 1972. Etude anatomique de la greffe d'un chataignier sur chene. Annals of Forest Science, 29 (3), 391- 395.

[12] Huang, H., J. D. Norton, G.E. Boyhan, and B.R. Abrahams, 1994. Graft compatibility among chestnut (Castanea) species. Journal of the American Society for Horticultural Science 119 (6): 1127-1132.

[13] Jefree, C. E. and M. M. Yeoman, 1983. Development of intercellular connections between opposing cells in a graft union. New Phytologist. 93, 491-509.

[14] McCully, M.E. 1983. Structural aspects of graft development. p.71-88 In: R. Moore (Editor). Vegetative Compatibility Responses in Plants. Baylor Univ. Press, Waco, TX.

[15] Moore, R. and D. B. Walker, 1981: Studies of vegetative compatibility-incompatibility in higher plants. I. A Structural study of a compatible autograft in Sedum telephoides (Crassulaceae). American Journal of Botany, $68,(6): 820-830$. 
[16] Mosse, B., 1962. Graft incompatibility in fruit trees. Technical Communication of the Commonwealth Bureau of Horticultural Plant Crops, 28: 1-36.

[17] Oraguzie, N. C., D. L. McNeil and M. B. Thomas, 1998. Examination of graft failure in New Zealand chestnut (Castanea spp) selections. Scientia Horticulturae, 76: 89103.

[18] Özçağıran, R. 1974. Physiological Relationships on Rootstock and Scion on Fruit Trees. Ege University Faculty of Agriculture, No: 243, İzmir. (In Turkish)

[19] Park, K.S. 1968. Studies on the juvenile tissue grafting of some special use- trees III. On the modified nurse seed grafting of some crop tree species (chestnut, ginkgo and oak). Res. Rpt. Inst. For. Gen. Korea 6:89-104.

[20] Pina, A. and P. Errea, 2005. A review of new advances in mechanism of graft compatibility-incompatibility. Scientia Horticulturae, 106: 1-11.

[21] Rutter, P. A., G. Miller and J. A. Payne, 1990. Chestnuts (Castanea). Acta Horticulturae. 20: 27-33.
[22] Santamour, F.S. 1988. Graft incompatibility related to cambial peroxidaz isozymes in Chinese chestnut. Journal of Enviromental Horticulture, 6 (2), p. 33-39.

[23] Seferoglu, G. and E. Ertan, 2003. Callus and graft union formation in Turkish chestnut selections. Bulletin of Pure Applied Science, 22B (2): 95-104.

[24] Serdar, Ü. and A. Soylu, 2004. Investigation of anatomical structure of graft union for $\mathrm{T}$ and inverted $\mathrm{T}$ buddings and whip grafting in chestnut. Acta Horticulturae (ISHS), 693: $165-170$

[25] Serdar, Ü., B. Köse and F. Yilmaz, 2005. The structure of Graft Unions in European Chestnut Using Different Grafting Methods. Hortscience, 40 (5): 1474-1477.

[26] Ufuk, S. and A. Soylu, 1999. Researches on stock-scion compatibility between some important chestnut cultivars and hybrid rootstocks. Acta Horticulturae, 494: 223-229. 